\title{
Tax Planning, Solvabilitas, Nilai Perusahaan, dan Ukuran Perusahaan sebagai Variabel Moderasi
}

\author{
Wisnu Haryo Pramudya ${ }^{(1)}$ \\ Program Studi Diploma Tiga Akuntansi \\ Akademi Akuntansi YKPN ${ }^{(1)}$ \\ Email: ${ }^{1}$ wisnu@ aaykpn.ac.id \\ Slamet Herutono $^{(2)}$ \\ Program Studi Diploma Empat Akuntansi Perpajakan \\ Akademi Akuntansi YKPN ${ }^{(2)}$ \\ Email: ${ }^{2}$ herutono@yahoo.com \\ Rahimah $^{(3)}$ \\ Program Studi Diploma Tiga Akuntansi \\ Akademi Akuntansi YKPN ${ }^{(3)}$ \\ Email: ${ }^{3}$ rahimah@aaykpn.ac.id
}

\begin{abstract}
Abstrak
Tujuan dari penelitian ini adalah untuk menguji pengaruh Tax Planning dan Solvabilitas terhadap Nilai Perusahaan dan menguji Ukuran Perusahaan apakah akan memperkuat pengaruh masingmasing variabel. Variabel independen dalam penelitian ini adalah Tax Planning dan Solvabilitas. Kemudian variabel dependennya adalah nilai perusahaan. Penelitian ini juga menggunakan Ukuran Perusahaan sebagai variabel moderasi. Hipotesis yang akan dibuktikan dalam penelitian ini adalah Tax Planning tidak berpengaruh terhadap Nilai Perusahaan, Solvabilitas berpengaruh terhadap Nilai Perusahaan, Ukuran Perusahaan tidak mampu memoderasi Tax Planning dengan Nilai Perusahaan, dan terakhir Ukuran Perusahaan mampu memperkuat pengaruh Solvabilitas dengan Nilai Perusahaan. Penelitian ini menggunakan MRA (Moderated Regression Analysis). MRA merupakan suatu bentuk regresi yang pada hakikatnya dirancang untuk mengetahui hubungan antara dua variabel yang dipengaruhi oleh variabel ketiga/moderator, suatu persamaan regresi yang mengandung unsur-unsur atau interaksi perkalian antara dua atau lebih variabel independen. Populasi penelitian ini adalah seluruh perusahaan real estate dan kontraktor yang terdaftar di Bursa Efek Indonesia (BEI) periode 2018-2020. Metode pengambilan sampel yang digunakan adalah purposive sampling. Hasil dari penelitian ini membuktikan seluruh hipotesis yang dibangun dapat diterima.

Kata Kunci: Tax Planning, Solvabilitas, Nilai Perusahaan.
\end{abstract}

\section{Abstract}

The purpose of this study are examine the effect of Tax Planning and Solvability on Firm Value and to test whether firm size will strengthen the influence of each variable. The independent variables in this study are Tax Planning and Solvability. Then the dependent variable is firm value. This study also using firm size as a moderating variable. The hypothesis that will be proven in this study is Tax Planning has no effect on Firm Value, Solvability has no effect on Firm Value, Firm Size could not moderate Tax Planning with Firm Value, and finally Firm Size could strengthen the effect of Solvability with Firm Value. This study using MRA (Moderated Regression Analysis). MRA is a form of regression which essentially designed to determine the relationship between two variables that influenced by a third/moderator variable, a regression equation consist of elements or multiplication interactions between two or more independent variables. The population of this study are all real estate companies and contractors listed on the Indonesia Stock Exchange (IDX) for the 2018-2020 period. The method of this sampling is purposive sampling. The results of this study prove that all hypotheses are acceptable.

Keywords: Tax Planning, Solvability, Firm Value. 


\section{PENDAHULUAN}

Berdasarkan laporan tahunan Dirjen Pajak, disebutkan bahwa penerimaan pajak tahun 2020 adalah sebesar Rp1.072,11 triliun, atau 89,43\% dari target penerimaan pajak. Proporsi penerimaan pajak berdasarkan jenis pajak adalah 52,33\% dari sektor $\mathrm{PPh}$ non migas, 3,08\% dari PPh Migas, 42\% dari PPN dan PPnBM, 1,95\% dari PBB, dan 0,63\% dari pajak lainnya. Sedangkan proporsi berdasarkan wajib pajak adalah $91,21 \%$ dari Wajib Pajak Orang Pribadi (WPOP), 7,67\% dari Wajib Pajak Badan (WP Badan) dan $1,12 \%$ dari Bendaharawan. Adapun catatan tentang kepatuhan Wajib Pajak dalam menyampaikan SPT Tahunan PPh dapat dikatakan cukup bagus dibandingkan dengan tahun 2019 yaitu 77,63\%, atau naik sebesar 6,26\%. Namun hal tersebut belum sesuai dengan harapan pemerintah untuk penerimaan pajak. Belum maksimalnya pencapaian target realisasi penerimaan pajak bisa jadi disebebakan karena wajib pajak melakukan upaya-upaya tertentu agar beban pajak yang mereka bayarkan lebih kecil. Hal tersebut kadangkala dilakukan dengan cara-cara yang tidak seluruhnya benar sesuai dengan aturan perundang-undangan perpajakan. Bila upaya tersebut tidak melanggar undang-undang perpajakan dengan cara wajib pajak mengelola pajaknya disebut dengan Tax Planning.

Perencanaan pajak/Tax Planning adalah langkah awal dalam manajemen pajak. Pada tahap ini dilakukan pengumpulan dan penelitian terhadap peraturan perpajakan agar dapat diseleksi jenis tindakan penghematan pajak yang akan dilakukan. Tujuan perencanaan pajak/Tax Planning adalah merekayasa agar beban pajak dapat ditekan serendah mungkin dengan memanfaatkan peraturan yang ada tetapi tidak melanggar undang-undang dan aturan perpajakan (Suandy, 2016). Tax Planning dapat dilihat dengan berbagai prespektif, salah satunya dengan prespektif Agency Theory. Masalah keagenan muncul apabila pihak-pihak yang saling berkepentingan bekerjasama dan memiliki tujuan dan pembagian kerja yang berbeda. Hubungan agensi muncul ketika seorang individu atau lebih sebagai prinsipal (stockholder), menugaskan kapada pihak yang lain sebagai agen (manager) dengan mendelegasikan tanggung jawab kepadanya. Teori keagenan ditekankan untuk mengatasi dua permasalahan yang dapat terjadi dalam hubungan keagenan, yaitu masalah keagenan yang timbul pada saat keinginan-keinginan prinsipal dan agen berlawanan dan merupakan suatu hal yang sulit atau mahal bagi prinsipal untuk melakukan verifikasi apakah agen telah melakukan sesuatu secara tepat. Dalam Agency Theory, aktivitas Tax Planning dapat memfasilitasi kesempatan manajer untuk melakukan tindakan oportunisme dengan memanipulasi laba atau penempatan sumber daya yang tidak sesuai serta kurang transparan dalam menjalankan operasional perusahaan sehingga Tax Planning berdampak negatif terhadap Nilai Perusahaan (Desai \& Dharmapala, 2005).

Menurut (Noerirawan \& Muid, 2012) nilai Perusahaan merupakan kepercayaan masyarakat terhadap perusahaan yang dilihat dari kondisi yang tekah dicapai oleh suatu perusahaan setelah melalui suatu kegiatan selama beberapa tahun, yaitu sejak berdirinya perusahaan tersebut hingga dengan saat ini. Sehingga dapat disimpulkan banwa nilai perusahaan dapat dilihat dari nilai pasar atau nilai buku perusahaan dari nilai ekuitasnya. Penelitian lainnya menunjukkan hasil bahwa semakin tinggi Tax Planning maka akan semakin tinggi perusahaan mengalami penurunan Nilai Perusahaan (Noviani, 2017). Hal ini akan semakin memberikan sinyal bagi pihak fiskus untuk lebih memperhatikan perusahaan tersebut. Akibatnya perusahaan harus bersiap untuk diperiksa dan menanggung kekurangan pajak beserta sanksi setelah dilakukan pemeriksaan.

Penelitian selanjutnya menunjukkan hasil bahwa semakin tingginya Nilai Perusahaan maka semakin menandakan keuntungan yang didapatkan tinggi. Keuntungan ini berasal dari memaksimalkannya aset-aset perusahaan. Hal ini sejalan dengan penelitian yang dilakukan oleh Januari \& Kartika, 2021 dan Rosharliantir, 2020 yang mengatakan bahwa Tax Planing berpengaruh positif terhadap Nilai Perusahaan. Namun 
penelitian lain yang dilakukan oleh Lestari, 2020 mengatakan bahwa Tax Planning tidak berpengaruh terhadap nilai perusahaan. Hal ini juga diungkapkan oleh penelitian Tambahani et al., 2021 bahwa Tax Planing tidak memiliki pengaruh terhadap nilai perusahaan. Sehingga, perlu diusulkan pemoderasi untuk mengatasi kesenjangan penelitian tersebut. Penelitian lain yang dilakukan tentang pengaruh Tax Planning terhadap return saham juga sudah pernah dilakukan oleh Pramudya, 2016. Penelitian Setiawan et al., 2021 mengungkapan bahwa ukuran perusahaan dapat meningkatkan nilai perusahaan. Sehingga diusulkan dengan menambahkan variabel moderasi, yaitu ukuran perusahaan, dengan total aset sebagai proksinya.

Banyak perusahaan beranggapan bahwa tujuan Tax Planning adalah hanya sekedar meminimkan jumlah pajak yang harus dibayarkan. Tujuan yang terpenting dari Tax Planning adalah mengurangi pajak tanpa mengganggu operasi perusahaan secara keseluruhan. Akan tetapi dalam praktiknya, terlalu konservatif dalam melakukan Tax Planning akan berdampak pada penurunan laba yang diperoleh perusahaan, dan jika laba berkurang maka akan mempengaruhi solvabilitas. Solvabilitas diukur dengan perbandingan antara total aktiva dengan total utang. Analisis Solvabilitas memiliki tujuan yaitu untuk mengetahui apakah kekayaan perusahaan mampu untuk mendukung kegiatan perusahaan tersebut. Untuk mengetahui tingkat Solvabilitas suatu perusahaan maka dapat dihitung dengan menggunakan rasio keuangan Debt Ratio. Dimana rasio total hutang dengan total aktiva yang biasa disebut rasio hutang (debt ratio), mengukur prosentase besarnya dana yang berasal dari hutang. Yang dimaksud dengan hutang adalah semua hutang yang dimiliki oleh perusahaan baik yang berjangka pendek maupun yang berjangka panjang. Kreditor lebih menyukai debt ratio yang renda sebab tingkat keamanan dananya menjadi semakin baik.

Adanya perbedaan pencatatan antara standar akuntansi dengan peraturan perpajakan, akan menimbulkan permasalahan yang kompleks dalam penyusunan laporan keuangan, yaitu laporan keuangan komersial dan laporan keuangan fiskal. Perbedaan ini memungkinkan manajemen untuk melakukan berbagai cara yang kreatif dalam membuat laporan keuangan. Ketika hal ini terjadi, maka biasanya peruahaan akan melakukan tindakan konservatif yang berarti bahawa perusahaan merasa pesimis dalam menghadapi tidak pastian laba atau rugi dengan memilih prinsip atau kebijakan mempelambat pengakuan pendapatan, mempercepat perlakuan biaya, merendahkan nilai aktiva dan meninggikan nilai utang, dengan demikian akan sangat berpengaruh terhadap nilai perusahaan. Dengan adanya perbedaan standar pelaporan ini mengakibatkan manajemen untuk bersiasat dalam membuat laporan keuangan, di satu sisi manajemen secara komersial akan melaporkan laba yang besar untuk menjamin kepercayaan publik, sedangkan untuk laporan pajak diupayakan untuk melaporkan laba sekecil mungkin untuk mengurangi beban pajak. Perusahaan yang ingin melaporkan kewajiban perpajakannya serendah mungkin akan melakukan Tax Planning semaksimal mungkin, sehingga mengurangi kewajiban pembayaran pajak perusahaan (da Silveira \& Barros, 2011).

Berdasarkan paparan di atas membuat peneliti bermaksud melakukan pengujian secara empiris mengenai Tax Planning dan Solvabilitas terhadap Nilai Perusahaan dengan melibatkan Ukuran Perusahaan. Ide besar dari penelitian ini adalah ingin mengetahui apakah Tax Planning yang dilakukan oleh perusahaan dapat mempengaruhi Nilai Perusahaan. Begitu juga dengan Solvabilitas apakah mempengaruhi Nilai perusahaan. Kemudian Ukuran Perusahaan apakah mampu memperkuat hubungan dari Tax Planning dan Solvabilitas terhadap Nilai Perusahaan. Peneliti berharap dengan mengetahui pengaruh Tax Planning dan Solvabilitas terhadap Nilai Perusahaan, perusahaan dapat berhati-hati dalam bertindak sehingga tidak merugikan kedepannya. Selain itu, bagi pemerintah atau fiskus memahami tindakan Tax Planning bukan 
merupakan sebuah tindakan kriminal.

\section{Pengembangan Hipotesis Penelitian}

Perencanaan pajak (Tax Planning) merupakan suatu tindakan yang dilakukan untuk meminimalkan beban pajak yang akan dibayarkan tanpa melanggar peraturan perundang-undangan yang berlaku. Yuliem, 2018 mengatakan bahwa Tax Planning tidak mempengaruhi Nilai Perusahaan. Jika Tax Planning berpengaruh, hal ini dapat semakin memberikan sinyal bagi pihak fiskus untuk lebih memperhatikan perusahaan tersebut. Akibatnya perusahaan harus bersiap untuk diperiksa dan menaggung kekurangan pajak beserta sanksi setelah dilakukan pemeriksaan, oleh karena itu dalam penelitian ini mengajukan hipotesis ke-1 yaitu:

\section{$\mathrm{H}_{1}$ : Tax Planning tidak berpengaruh terhadap Nilai Perusahaan.}

Rasio solvabilitas adalah rasio yang menunjukkan kemampuan perusahaan dalam membayar seluruh kewajibannya, baik itu kewajiban jangka panjang maupun kewajiban jangka pendeknya. Apabila perusahaan mempunyai aktiva ataupun kekayaan yang cukup untuk membayar semua hutang-hutangnya maka perusahaan tersebut dapat dikatakan solvabel, dan dikatakan insolvabel jika jumlah aktiva tidak cukup atau lebih kecil daripada jumlah hutang perusahaan. Jika solvabel maka akan neningkatkan nilai perusahaan, oleh karena itu dalam penelitian ini mengajukan hipotesis ke-2 yaitu:

\section{$\mathrm{H}_{2}$ : Solvabilitas berpengaruh terhadap Nilai Perusahaan}

Menurut Setiawati, 2018 Ukuran Perusahaan memiliki pengaruh terhadap Nilai Perusahaan. Perusahaan besar cenderung memiliki aset dalam jumlah yang banyak, sehingga menyebabkan keleluasaan manajemen dalam menggunakan aset untuk meningkatkan nilai perusahaan. Mereka telah menyadari bahwa perusahaan dengan kapasitas besar menjadi sorotan pihak fiskus. Akan tetapi ukuran perusahaan yang di proksikan dengan Total Aset, tidak mempengaruhi kewajiban perpajakan, karena yang sangat mempengaruhi kewajiban perpajakan adalah laba. Oleh karena itu dalam penelitian ini mengajukan hipotesis ke-3 yaitu:

\section{$\mathrm{H}_{3}$ : Ukuran Perusahaan tidak memoderasi pengaruh Tax Planning terhadap Nilai} Perusahaan.

Hasil penelitian yang dilakukan oleh Rompas, 2016 ditemukan bahwa Solvabilitas berpengaruh terhadap Nilai Perusahaan dan di penelitian yang ditemukan oleh Mahendra et al., 2012 hasil penelitiannya menemukan hasil yang berbeda bahwa debt to equity rasio yang menjadi varibael pengukur Solvabilitas berpengaruh negatif signifikan terhadap Nilai Perusahaan. Oleh karena itu dengan adanya moderasi dari ukuran perusahaan, akan dapat memeperjelas kesimpulan bahawa ukuran perusahaan memoderasi lebih baik antara solvabilitas dengan nilai perusahaan, oleh karena itu dalam penelitian ini mengajukan hipotesis ke-4 yaitu:

H4: Ukuran Perusahaan memoderasi pengaruh solvabilitas terhadap Nilai Perusahaan. 


\section{METODE PENELITIAN}

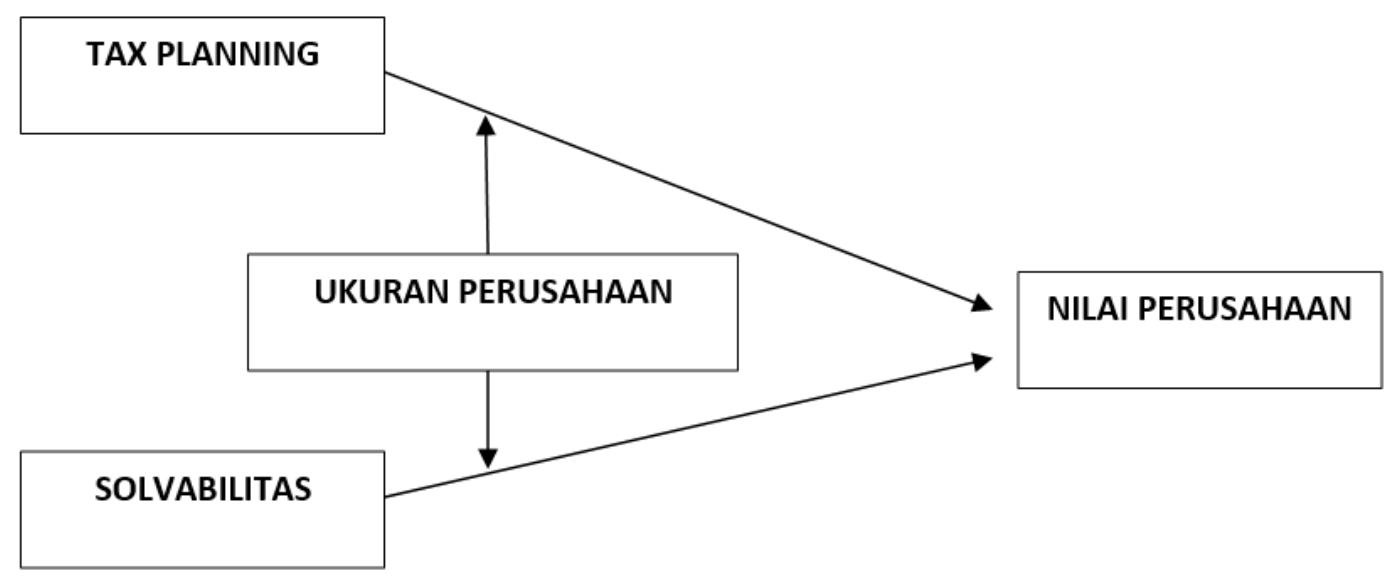

Gambar 1.1 Rancangan Penelitian

Data yang digunakan dalam penelitian ini adalah data sekunder dari perusahaan Real Estate dan Kontraktor yang terdaftar di Bursa Efek Indonesia (BEI). Data-data tersebut diperoleh dari JSX data base dan Indonesian Capital Market Directory. Datadata tersebut berupa laporan keuangan perusahaan Real Estate dan Kontraktor yang terdaftar di Bursa Efek Indonesia (BEI) dan harga penutupan saham. Populasi dalam penelitian ini adalah seluruh perusahaan-perusahaan Real Estate dan Kontraktor yang terdaftar di Bursa Efek Indonesia (BEI) dengan periode pengamatan dari tahun 2018 sampai dengan tahun 2020. Metode pengambilan sampel yang digunakan adalah "purposive sampling", sehingga sampel penelitian yang diambil adalah sampel yang memenuhi kriteria dalam penelitian ini. Kriteria pemilihan sampel dalam penelitian ini adalah perusahaan tersebut terdaftar di Bursa Efek Indonesia (BEI) mulai tahun 2018 sampai dengan tahun 2020 dan mempublikasikan laporan keuangan secara lengkap berturut-turut dari tahun 2018 sampai dengan tahun 2020.

Variabel dependen dalam penelitian ini adalah nilai perusahaan. Nilai perusahaan merupakan persepsi investor terhadap tingkat keberhasilan manajer dalam mengelola sumber daya perusahaan yang dipercayakan kepadanya yang sering dihubungkan dengan harga saham. Nilai perusahaan dapat diketahui dengan menggunakan Price Book Value (PBV). Price to Book Value atau PBV adalah rasio yang menunjukkan apakah harga saham yang diperdagangkan overvalued (di atas) atau undervalued (di bawah) nilai buku saham tersebut. PBV menggambarkan seberapa besar pasar menghargai nilai buku saham suatu perusahaan. Makin tinggi rasio ini, berarti pasar percaya akan prospek perusahaan tersebut. PBV juga menunjukkan seberapa jauh suatu perusahaan mampu menciptakan nilai perusahaan yang relatif terhadap jumlah modal yang diinvestasikan. Rumus PBV adalah sebagai berikut:

$$
\mathrm{PBV}=\frac{\text { Harga Saham }}{\text { Nilai Buku per Saham* }}
$$

*Book Value / Nilai Buku = Total Ekuitas / Jumlah Saham Beredar 
Variabel independen yang pertama dalam penelitian ini adalah Perencanaan Pajak/Tax Planning dengan menggunakan Tarif Pajak Efektif (effective tax rate). ETR sering dipakai oleh pembuat keputusan dalam perusahaan untuk menilai kelayakan suatu system pajak yang terkait dengan perusahaan (badan). Effective Tax Rate (ETR) merupakan presentase besarnya beban pajak efektif yang harus dibayarkan suatu perusahaan pada tahun berjalan. ETR menggambarkan presentase total beban pajak penghasilan yang dibayarkan perusahaan dari seluruh total pendapatan sebelum pajak yang diperoleh perusahaan (Pradipta \& Supriyadi, 2015). Nilai ETR yang semakin rendah menunjukkan adanya tindakan tax avoidance yang semakin tinggi yang dilakukan oleh suatu perusahaan. Adapun rumus ETR adalah:

$$
\text { ETR }=\frac{\text { Total Tax Expense }}{\text { Pre Tax income }}
$$

Variabel indepanden yang kedua dalam penelitian ini adalah Solvabillitas. Penelitian ini menggunakan rasio total hutang dengan total aktiva yang biasa disebut rasio hutang (debt ratio), mengukur prosentase besarnya dana yang berasal dari hutang. Untuk mengukur debt ratio biasanya menggunakan rumus sebagai berikut:

$$
\text { Debt Ratio }=\frac{\text { TotalHutang }}{\text { Total Aset }} \times 100 \%
$$

Kemudian penelitian ini juga menggunakan variabel moderasi berupa Ukuran Peruahaan yang diproksikan dengan jumlah total aset. Semakin besar total aset, diasumsikan jumlah tersebut akan mempengaruhi pengaruh Tax Planning dan Solvabilitas terhadap nilai perusahaan.

Pengujian hipotesis dilakukan dengan menggunakan Moderated Regression Analysis (MRA). MRA merupakan suatu bentuk regresi yang dirancang secara hirarki untuk menetukan hubungan antara dua variabel yang dipengaruhi oleh variabel ketiga atau variabel moderator, yang persamaan regresinya mengandung unsur interaksi atau perkalian antara dua atau lebih variabel independen. Persamaan regresi untuk penelitian ini adalah sebagai berikut:

$$
\mathrm{NP}=\alpha+\beta 1 \mathrm{ETR}+\beta 2 \mathrm{SLV}+\beta 3 \mathrm{UP}+\beta 4 \mathrm{ETR} * \mathrm{UP}+\beta 5 \mathrm{SLV} * \mathrm{UP}+\varepsilon
$$

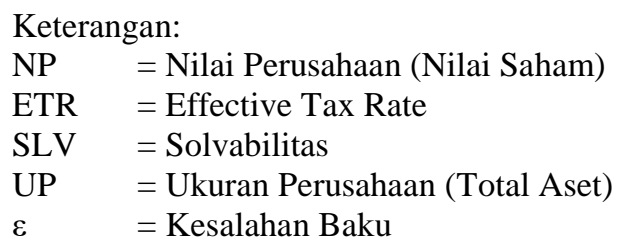




\section{ANALISIS DAN PEMBAHASAN}

Penelitian ini dianalisis dengan menggunakan alat analisis model regresi linier berganda (multiple regression model) dengan metoda kuadrat terkecil biasa atau ordinary least square method yang digunakan untuk mengetahui pengaruh keseluruhan variabel independen Tax Planning dan Solvabilitas, serta Ukuran Perusahaan sebagai variabel moderasi, terhadap Nilai Perusahaan. Model regresi yang diperoleh dari metode kuadrat terkecil biasa (ordinary least squares) merupakan model regresi yang menghasilkan estimator linear tidak bias yang terbaik. Kondisi ini akan terjadi apabila terpenuhinya beberapa asumsi klasik. Model yang digunakan untuk pengujian asumsi klasik yaitu uji normalitas data, uji Multikolineritas, uji autokorelasi dan uji heteroskedastisitas. Asumsi klasik model regresi telah diuji sebelum analisis regresi dilakukan. Dan hasilnya menunjukkan bahwa data terdistribusi normal, tidak ada masalah terhadap multikolineritas, heterokedastisitas, autokorelasi dan tidak ada outlier dalam data.

Penelitian ini menggunakan pengujian analisis regresi linear berganda dengan tingkat signifikansi $\alpha=5 \%$. Analisis tersebut bertujuan untuk menguji hipotesis. Hasil uji hipotesis dengan regresi disajikan dalam tabel 1 berikut ini:

Tabel 1 Analisis Regresi

\begin{tabular}{cccc}
\hline $\mathbf{N P}=\boldsymbol{\alpha}+\boldsymbol{\beta}_{\mathbf{1}} \mathbf{E T R}+\boldsymbol{\beta}_{\mathbf{2}} \mathbf{S L V}+\boldsymbol{\beta 3} \mathbf{U P}+\boldsymbol{\beta 4} \mathbf{E T R} * \mathbf{U P}+\boldsymbol{\beta 5} \mathbf{S L V} \mathbf{U P}+\boldsymbol{\varepsilon}$ & \\
\hline Variabel & \multicolumn{1}{c}{ Koefisien } & t-Statistik & Sig \\
\hline Konstanta & $1.130,598$ & 6,087 & - \\
ETR & $-0,013$ & $-0,130$ & 0,897 \\
SLV & $0,415^{* * *}$ & 3,975 & 0,000 \\
UP & $0,407^{* * *}$ & 3,111 & 0,003 \\
Mod_ETR*UP &,- 087 & $-0,689$ & 0,493 \\
Mod_SLV*UP & $-0,82^{* * *}$ & $-5,627$ & 0,000 \\
Adjusted R-squared & 0,351 & & \\
F-statistik & $9,445^{* * *}$ & & 0,000 \\
\hline
\end{tabular}

*** menunjukkan bahwa koefisien signifikan pada level 0,01.

Hasil pada tabel 1, menunjukkan nilai $\mathrm{R}$ Square sebesar 0,351 atau $35,1 \%$. Nilai tersebut menunjukkan bahwa $35,1 \%$ dari total variasi dalam variabel dependen Nilai Perusahaan dijelaskan oleh variasi-variabel yang dimasukkan dalam model yaitu ETR, SLV, Mod_ETR*UP, dan Mod_SLV*UP, setelah mempertimbangkan banyaknya variabel independen dan ukuran sampel. Sedangkan sisanya sebesar 64,9\% dijelaskan oleh variabel-variabel lain di luar model. Uji $t$ atau $t$ test dapat digunakan untuk mengetahui pengaruh variabel independen secara sendiri-sendiri terhadap variabel dependen. Sebuah variabel dinyatakan mempengaruhi variabel dependennya jika nilai thitung lebih dari t-tabel atau probabilitasnya atau signifikansinya kurang dari 0,05.

Kriteria yang digunakan adalah apabila nilai signifikansi t-hitung lebih besar dari $\alpha=5 \%$, berarti variabel independen tidak berpengaruh secara signifikan terhadap variabel dependennya. Demikian pula sebaliknya, apabila nilai signifikansi t-hitung lebih kecil daripada $\alpha=5 \%$, maka berarti variabel independen berpengaruh secara signifikan 
terhadap variabel dependennya. Dari hasil regresi dapat dilihat bahwa semua variabel mempunyai nilai t-statistik yang signifikansinya kurang dari 0,05 . Dari hasil tersebut dapat dikatakan semua variabel independen signifikan secara statistik berpengaruh terhadap variabel dependennya.

Uji Anova atau $F$ test merupakan pengujian secara bersama-sama terhadap variabel independen. Pengujian koefisien regresi dengan F-statistik dilakukan dua sisi dengan tingkat kepercayaan 95\%. Variabel-variabel independen dinyatakan signifikan mempengaruhi variabel dependennya secara bersama-sama jika nilai $\mathrm{F}$ table atau signifikansinya kurang dari $\alpha=5 \%$. Dari hasil estimasi diperoleh nilai F-statistik sebesar 9,445 dengan signifikansinya 0,000. Karena nilai signifikansinya lebih kecil dari 0,05, maka dapat dikatakan bahwa nilai F-statistik tersebut signifikan secara statistik berpengaruh secara bersama-sama seluruh variabel independen terhadap variabel dependennya. Dari pengujian tersebut dapat diakatakan model penelitian fit.

Pengaruh Tax Planning terhadap Nilai Perusahaan.

Pada tabel 1 koefisien ETR adalah -0,13 dengan tingkat signifikansi sebesar 0,897 dengan mengunakan tingkat $\alpha=5 \%$. Variabel ETR tidak signifikan karena mempunyai nilai lebih besar dari tingkat signifikansinya atau 0,897 >0.05. Pengujian hipotesis pertama menunjukkan bahwa secara statistik penelitian ini berhasil membuktikan Tax Planning tidak berpengaruh terhadap Nilai Perusahaan. Dengan demikian, penelitian ini dapat menerima hipotesis pertama $\left(\mathrm{H}_{1}\right)$. Hal ini berarti manajemen dalam melaksanakan tax planning, tidak termotivasi dengan nilai perusahaan yang akan dihasilkan, tetapi lebih ke bagaimana pajak yang harus dibayarkan lebih kecil tanpa memperhitungkan harga saham.

Pengaruh Solvabilitas terhadap Nilai Perusahaan.

Pada tabel 1 koefisien SLV adalah 0,415 dengan tingkat signifikansi sebesar 0,000 dengan mengunakan tingkat $\alpha=5 \%$. Variabel SLV signifikan berpengaruh terhadap Nilai Perusahaan karena mempunyai nilai lebih kecil dari tingkat signifikansinya atau $0,000<0.05$. Pengujian hipotesis kedua menunjukkan bahwa secara statistik penelitian ini berhasil membuktikan solvabilitas berpengaruh terhadap Nilai Perusahaan. Dengan demikian, penelitian ini dapat menerima hipotesis kedua $\left(\mathrm{H}_{2}\right)$. Hal ini menunjukkan bahwa manajemen mengelola utangnya dengan baik sehingga memiliki jumlah aset yang cukup untuk menjamin utang perusahaan. Kemudian aset tersebut dapat meningkatkan nilai perusahaan karena tingkat kepercayaan kepada perusahaan akan lebih tinggi dan akan berpengaruh pada harga saham.

Pengaruh Ukuran Perusahaan terhadap hubungan antara Tax Planning dengan Nilai Perusahaan

Pada tabel 1 koefisien Mod_ETR*UP adalah -0,087 dengan tingkat signifikansi sebesar 0,493 dengan mengunakan tingkat $\alpha=5 \%$. Variabel Mod_ETR*UP tidak signifikan berpengaruh terhadap Nilai Perusahaan karena mempunyai nilai lebih besar dari tingkat signifikansinya atau 0,493 > 0.05. Pengujian hipotesis ketiga menunjukkan bahwa secara statistik penelitian ini berhasil membuktikan Mod_ETR*UP tidak berpengaruh terhadap hubungan antara Tax Planning dengan Nilai Perusahaan. Dengan demikian, penelitian ini dapat menerima hipotesis ketiga $\left(\mathrm{H}_{3}\right)$. Hal ini dapat dikatakan bahwa seberapun ukuran perusahaan yang diproksikan dengan total aset yang dimiliki perusahaan tidak mempengaruhi hubungan antara Tax Panning dengan Nilai Perusahaan.

Pengaruh Ukuran Perusahaan terhadap hubungan antara Solvabilitas dengan Nilai Perusahaan

Pada tabel 1 koefisien Mod_SLV*UP adalah -0,820 dengan tingkat signifikansi sebesar 0,000 dengan mengunakan tingkat $\alpha=5 \%$. Variabel Mod_SLV*UP signifikan berpengaruh terhadap Nilai Perusahaan karena mempunyai nilai lebih kecil dari tingkat signifikansinya atau $0,000<0.05$. Pengujian hipotesis keempat menunjukkan bahwa secara statistik penelitian ini berhasil membuktikan Mod_KSV*UP berpengaruh terhadap hubungan antara Solvabilitas dengan Nilai Perusahaan. Dengan demikian, penelitian ini 
dapat menerima hipotesis keempat $\left(\mathrm{H}_{4}\right)$. Hal ini dapat dikatakan bahwa ukuran perusahaan yang diproksikan dengan total aset yang dimiliki perusahaan mempengaruhi hubungan antara solvabilitas dengan Nilai Perusahaan.

\section{PENUTUP}

Penelitian ini menghasilkan bukti secara empiris mengenai Tax Planning tidak mempengaruhi Nilai Perusahaan yang sejalan dengan penelitian sebelumnya. Tax Planning merupakan tindakan yang diperbolehkan selama tidak melanggar undangundang. Kemudian tindakan perusahaan melakukan Tax Planning tidak membuat Nilai Perusahaan turun ataupun naik. Dari sisi fiskus atau pemerintah harus memahami tindakan Tax Planning sebagai salah satu cara perusahaan meminimalisasi pembayaran pajak dengan memanfaatkan aturan perpajakan secara maksimal. Nilai perusahaan akan lebih terpengaruh dengan solvabilitas. Hal ini sejalan dengan hasil penelitian yang kami lakukan. Solvabilitas yang dapat diukur dengan debt ratio memiliki pengaruh terhadap Nilai Perusahaan. Para investor atau kreditur akan menilai perusahaan berdasarkan aset dan kewajiban yang dimiliki. Kesehatan perusahaan pun dapat dinilai dari sana. Sehingga perusahan yang memiliki debt ratio paling kecil tentunya akan mempunyai nilai perusahaan yang tinggi.

Penelitian ini juga memasukkan ukuran perusahaan sebagai variabel moderasi dalam hubungan Tax Planning dan Solvabilitas terhadap Nilai Perusahaan. Hasil dari penelitian ini membuktikan bahwa Ukuran Perusahaan tidak mampu mempengaruhi hubungan Tax Planning dengan Nilai Perusahaan. Semakin besar perusahaan kemungkinan untuk melakukan Tax Planning semakin besar pula. Namun itu tidak membuat nilai perusahaan mereka juga berubah. Nilai perusahaan akan bisa langsung dipengaruhi oleh ukuran perusahaan seperti penelitian sebelumnya. Para investor dan kreditur lebih memperhatikan hal-hal yang pasti seperti aset dan kewajiban yang dimiliki oleh perusahaan. Terbukti melalui penelitian ini Ukuran Perusahaan mampu mempengaruhi hubungan Solvabilitas terhadap Nilai Perusahaan. Semakin besar ukuran perusahaan yang terlihat dari aset yg dimiliki perusahaan akan semakin bernilai. Aset yang dimiliki dapat melunasi kewajiban dalam jangka pendek sehingga perusahaan mempunya solvabilitas yang tidak diragukan oleh para investor atau kreditur.

\section{DAFTAR PUSTAKA}

da Silveira, A. D. M., \& Barros, L. A. B. de C. (2011). Corporate Governance Quality and Firm Value in Brazil. SSRN Electronic Journal. https://doi.org/10.2139/ssrn.923310

Desai, M. A., \& Dharmapala, D. (2005). Corporate Tax Avoidance and High Powered Incentives. SSRN Electronic Journal. https://doi.org/10.2139/ssrn.532702

Januari, \& Kartika, S. I. (2021). Pengaruh Perencanaan Pajak Dan Kinerja Keuangan Terhadap Nilai Perusahaan Pada Perusahaan Farmasi Yang Terdaftar Di Bursa Efek Indonesia. Proceding Seminar Nasional Kewirausahaan, 2(1), 907-915. https://doi.org/http://dx.doi.org/10.30596\%2Fsnk.v2i1.8405

Jogiyanto. (2005). Metodologi Penelitian Bisnis Salah Kaprah dan PengalamanPengalaman (Edisi 6). BPFE Yogyakarta.

Lestari, P. G. (2020). Pengaruh Tax Planning Dan Leverage Terhadap Nilai Perusahaan (Penelitian Pada Perusahaan Pertambangan Yang Terdaftar Di Bursa Efek Indonesia 2016-2018). Jurnal Penelitian Ekonomi Dan Akuntansi, 5(3), 256-261.

Mahendra, A., Sri artini, L. gede, \& Suarjaya, A. G. (2012). Pengaruh Kinerja Keuangan Terhadap Nilai Perusahaan Manufaktur di Bursa Efek Indonesia. Jurnal Manajemen, Stategi Bisnis, Dan Kewirausahaan, 6(2), 130-138. 
Noerirawan, M. R., \& Muid, A. (2012). PENGARUH FAKTOR INTERNAL DAN EKSTERNAL PERUSAHAAN TERHADAP NILAI PERUSAHAAN (Studi Empiris pada Perusahaan Manufaktur yang terdaftar di Bursa Efek Indonesia Periode 2007-2010). PENGARUH FAKTOR INTERNAL DAN EKSTERNAL PERUSAHAAN TERHADAP NILAI PERUSAHAAN (Studi Empiris Pada Perusahaan Manufaktur Yang Terdaftar Di Bursa Efek Indonesia Periode 20072010), 1(1), 582-593.

Noviani, A. S. (2017). Pengaruh Perencanaan Pajak, Manajemen Laba Dan Good Corporate Governance Terhadap Nilai Perusahaan. Skripsi Univesitas Islam Negeri Syarif Hidayatullah.

Pradipta, D. H., \& Supriyadi. (2015). Pengaruh Corporate Social Responsibility (CSR), Profitabilitas, Leverage, Dan Komisaris Independen Terhadap Praktik Penghindaran Pajak. Kompartemen Jurnal Ilmiah Akuntansi, Vol.XV(No.1), PP.1-25.

Pramudya, W. H. (2016). Pengarauh Tax Planning Terhadap Return Saham Yang Dimoderasi Oleh Konservatisma Akuntansi Dengan Variabel Kontrol Ukuran. WAHANA Volume 19, No. 1, Februari 2016, 19(1).

Rompas, G. P. (2016). Likuiditas, Solvabilitas dan Rentabilitas Terhadap Nilai Perusahaan BUMN Yang Terdaftar Di BEI. Jurnal EMBA, 1(3), 252-262.

Rosharliantir, Z. (2020). Peran Pengungkapan Csr Dalam Memoderasi Pengaruh Penerapan Tax Planning Dan Ios TERHADAP NILAI PERUSAHAAN. EkoPreneur, 2(1), 93-104.

Setiawan, M. R., Susanti, N., \& Nugraha, N. M. (2021). Pengaruh Struktur Modal Dan Ukuran Perusahaan Terhadap Nilai Perusahaan. Owner: Riset \& Jurnal Akuntansi. https://doi.org/10.47232/aktual.v17i1.34

Setiawati, L. W. (2018). Analisis Pengaruh Profitabilitas, Ukuran Perusahaan, Leverage, Dan Pengungkapan Sosial Terhadap Nilai Perusahaan Pada Perusahaan Manufaktur Yang Terdaftar Di Bursa Efek Indonesia Periode 2011-2015. Jurnal Akuntansi, 12(1), 29-57. https://doi.org/10.25170/jara.v12i1.57

Suandy, E. (2016). Perencanaan Pajak (Edisi 6). Salemba Empat.

Tambahani, G. D., Sumual, T. E. M., \& Kewo, C. (2021). Pengaruh Perencanaan Pajak (Tax Planning) dan Penghindaran Pajak (Tax Avoidance) Terhadap Nilai Perusahaan. Jurnal Akuntansi Manado (JAIM), 2(2), 142-154. https://doi.org/10.53682/jaim.v2i2.1359

Yuliem, M. L. (2018). Pengaruh Perencanaan Pajak (Tax Planning) Terhadap Nilai Perusahaan (Firm Value) Pada Perusahaan Sektor Non Keuangan Yang Terdaftar Di BEI Periode 2013-2015. Calyptra, 7(1), 520-540. 